\title{
Inappropriate Shock
}

National Cancer Institute

\section{Source}

National Cancer Institute. Inappropriate Shock. NCI Thesaurus. Code C63093.

Problem associated with the inappropriate delivery of an electrical energy. 